\title{
Faktor Prognosis Sindrom Syok Dengue pada Anak
}

Hindra Irawan Satari, Rossy Agus Mardani, Hartono Gunardi

Departemen Ilmu Kesehatan Anak Fakultas Kedokteran Universitas Indonesia/RSUPN dr. Cipto Mangunkusumo, Jakarta

Latar belakang. Manifestasi klinis yang bervariasi, patogenesis yang kompleks, dan perbedaan serotipe virus membuat sulit memprediksi perjalanan penyakit dengue. Banyak penelitian yang telah dilakukan tentang faktor prognosis terjadinya sindrom syok dengue (SSD), tetapi semuanya menggunakan pedoman World Health Organization (WHO) tahun 1997.

Tujuan. Penelitian ini bertujuan mengetahui faktor-faktor prognosis terjadinya SSD berdasarkan pedoman WHO tahun 2011. Metode. Studi retrospektif menggunakan data rekam medik pasien anak usia 0 sampai $<18$ tahun dengan diagnosis demam berdarah dengue (DBD), SSD dan expanded dengue syndrome (EDS) yang memenuhi kriteria WHO tahun 2011 di RSCM dari Januari 2013 sampai Desember 2016. Variabel independen, yaitu jenis kelamin, usia, status gizi, infeksi dengue sekunder, leukopenia, nyeri abdomen, perdarahan gastrointestinal, hepatomegali dan kebocoran plasma. Syok merupakan variabel dependen. Analisis multivariat menggunakan analisis regresi logistik.

Hasil. Subyek yang memenuhi kriteria penelitian 145 pasien, 52 (35,8\%) di antaranya mengalami SSD. Lima dari 52 pasien SSD mengalami syok selama perawatan di rumah sakit. Analisis bivariat yang menghasilkan faktor-faktor signifikan di antaranya, malnutrisi, gizi lebih dan obesitas, perdarahan gastrointestinal, hemokonsentrasi, asites, leukosit $\geq 5.000 \mathrm{~mm}^{3}$, ensefalopati, peningkatan enzim hati dan overload. Hasil analisis multivariat menunjukkan variabel hemokonsentrasi dan peningkatan enzim hati merupakan faktor prognosis SSD.

Kesimpulan. Hemokonsentrasi dan peningkatan enzim hati merupakan faktor prognosis terjadinya SSD. Sari Pediatri 2018;20(3):131-7

Kata kunci: anak, demam berdarah dengue, prognosis, syok

\section{Prognosis Factors of Dengue Shock Syndrome in Children}

\author{
Hindra Irawan Satari, Rossy Agus Mardani, Hartono Gunardi
}

Background. Various clinical manifestations, complex pathogenesis, and different virus serotypes make us difficult to predict the course of dengue. Many kinds of research about prognostic factors of dengue shock syndrome had been done despite upon on WHO 1997 guideline.

Objective. To know prognosis factors in Dengue Hemorrhagic Fever (DHF) which have a potency to become DSS.

Methods. Retrospective study uses medical records of children age 0 until $<18$ years old with DHF diagnosis who fulfill WHO 2011 criteria from January 2013 until December 2016. Independent variables are sex, age, nutritional status, secondary dengue infection, leucopenia, abdominal tenderness, gastrointestinal bleeding, hepatomegaly, and plasma leakage. Shock prognosis factor is a dependent variable. Multivariate analysis uses logistic regression analysis.

Results. Subjects who fulfill study criteria were 145 patients, 52 patients $(35,8 \%)$ among them had a diagnosis of DSS. Five of 52 patients with DSS had shock during hospitalized. The bivariate analysis yielded significant factors: malnutrition, overnutrition, gastrointestinal bleeding, hemoconcentration, ascites, leucocyte $\geq 5.000 / \mathrm{mm}^{3}$, encephalopathy, elevated liver enzymes, and overload. The result of multivariate analysis showed that hemoconcentration and elevated liver enzymes were prognosis factors of DSS. Conclusion. Hemoconcentration and elevated liver enzymes are prognosis factors of dengue shock syndrome. Sari Pediatri 2018;20(3):131-7

Keywords: children, dengue haemorrhagic fever, prognosis, shock

Alamat korespondensi: Hindra Irawan Satari. Departemen Ilmu Kesehatan Anak Fakultas Kedokteran Universitas Indonesia. Jl. Salemba Raya no. 6 , Jakarta Pusat, 10430. E-mail: hsatari@ikafkui.net 
M anifestasi klinis yang sangat bervariasi, patogenesis yang kompleks, dan perbedaan serotipe virus pada daerah yang berbeda, membuat kita sulit memprediksi perjalanan penyakit dengue apalagi dalam menilai apakah pasien akan menjadi syok atau syok berulang. ${ }^{1}$ Pencarian faktor prognosis terasa sangat penting dalam memprediksi kasus yang mungkin berkembang menjadi SSD. ${ }^{2}$

Banyak penelitian yang telah dilakukan di Indonesia atau di luar negeri tentang faktor prognosis terjadinya syok pada pasien anak demam berdarah dengue (DBD). Semua penelitian sebelumnya menggunakan pedoman World Health Organization (WHO) tahun 1997 tentang tata laksana infeksi virus dengue. ${ }^{2-13}$ Angka kematian SSD 7,81\% dan prevalensi SSD $15,53 \%{ }^{3}$ yang tinggi serta klasifikasi infeksi virus dengue terbaru menurut pedoman WHO $2011^{14}$ dengan kelompok baru expanded dengue syndrome (EDS) merupakan alasan dilakukannya penelitian ini. Expanded dengue syndrome dapat berhubungan dengan syok pada DBD. $3,14,15$

Tujuan penelitian ini untuk mengetahui faktorfaktor prognosis pada infeksi virus dengue yang berpotensi menjadi sindrom syok dengue berdasarkan pedoman WHO tahun 2011 tentang tata laksana infeksi virus dengue.

\section{Metode}

Penelitian ini merupakan studi prognosis yang bersifat kohort retrospektif. Faktor prognosis yang diteliti, yaitu jenis kelamin, usia, status gizi, infeksi dengue sekunder, leukopenia, nyeri abdomen, perdarahan gastrointestinal, hepatomegali, dan kebocoran plasma. Penelitian ini dilakukan di Departemen Ilmu Kesehatan Anak RSCM, data diambil dari rekam medis. Subyek penelitian ini adalah anak usia $0-<18$ tahun dengan diagnosis DBD, SSD dan EDS yang dirawat di RSCM sejak 1 Januari 2013 sampai 31 Desember 2016.

Jumlah sampel dihitung menggunakan rumus rule of thumb dan didapat hasil 145 subyek. Pengambilan sampel dilakukan secara consecutive sampling. Variabel tergantung adalah sindrom syok dengue. Variabel bebas adalah jenis kelamin, usia, status gizi, infeksi dengue sekunder, leukopenia, nyeri abdomen, perdarahan gastrointestinal, hepatomegaly, dan kebocoran plasma.
Data diolah dengan program SPSS versi 14.0. Analisis statistik menggunakan analisis bivariat, analisis multivariat dengan regresi logistik, dan analisa kurva ROC. Penelitian ini telah mendapatkan persetujuan Komisi Etik Penelitian Fakultas Kedokteran Universitas Indonesia (FKUI)-RSCM.

\section{Hasil}

Data rekam medis diambil sejak 1 Januari 2013 sampai 31 Desember 2016. Terdapat 400 data rekam medis subyek dengan infeksi virus dengue. Seratus sembilanbelas rekam medis tidak lengkap. Seratus tigapuluh enam subyek dieksklusi karena 100 terdiagnosis DD, 36 hematologi onkologi dan infeksi. Subyek yang memenuhi kriteria inklusi 145 subyek, $44(30,3 \%)$ di antaranya mengalami EDS.

Tabel 1. Karakteristik klinis subyek penelitian $(\mathrm{n}=145)$

\begin{tabular}{lc}
\hline Karakteristik & Jumlah, n (\%) \\
\hline Usia (tahun) & $12(8,3)$ \\
$0-<1$ & $21(14,5)$ \\
$1-<5$ & $58(40)$ \\
$5-10$ & $54(37,2)$ \\
$>10-<18$ & $73(50,3)$ \\
Jenis kelamin lelaki & \\
Status gizi & $2(1,4)$ \\
Buruk & $39(26,9)$ \\
Kurang & $72(49,7)$ \\
Baik & $10(6,9)$ \\
Lebih & $22(15,2)$ \\
Obesitas & $98(67,6)$ \\
Nyeri abdomen & $41(28,3)$ \\
Hepatomegali & $17(11,7)$ \\
Perdarahan gastrointestinal & \\
Manifestasi perdarahan saluran cerna & $10(6,9)$ \\
Hematemesis & $5(3,4)$ \\
Melena & $2(1,4)$ \\
Hematokezia & \\
Manifestasi perdarahan non GI & $74(51,0)$ \\
Petekie & $17(11,7)$ \\
Epistaksis & $11(7,6)$ \\
Gusi berdarah & $20(13,8)$ \\
Efusi pleura & $3(2,1)$ \\
Asites & \\
\hline &
\end{tabular}




\begin{tabular}{lc}
\hline Karakteristik & Jumlah, n (\%) \\
\hline Expanded dengue syndrome (EDS) & $44(30,3)$ \\
Ensefalopati & $14(9,6)$ \\
Peningkatan enzim hati & $21(14,5)$ \\
Overload & $18(12,4)$ \\
AKI & $2(1,4)$ \\
Koinfeksi & \\
$\quad$ Diare akut & $1(0,7)$ \\
ISK & $1(0,7)$ \\
Konjungtivitis & $1(0,7)$ \\
Imbalans elektrolit & \\
Hipokalemia & $1(0,7)$ \\
Hiponatremia & $7(4,8)$ \\
\hline
\end{tabular}

Analisis bivariat menghasilkan beberapa faktor prognostik yang bermakna $(p<0,05)$, yaitu gizi buruk-kurang (malnutrisi) terhadap gizi baik, gizi lebih-obesitas terhadap gizi baik, perdarahan saluran

Tabel 2. Karakteristik laboratoris subyek penelitian

\begin{tabular}{lc}
\hline Karakteristik & Jumlah, $\mathrm{n}(\%)$ \\
\hline Infeksi dengue sekunder $(\mathrm{n}=109)$ & $52(47,7)$ \\
Hemokonsentrasi (peningkatan hematokrit & $100(69)$ \\
$\geq 20 \%)$ & $60(41,4)$ \\
Leukosit $<5000 \mu \mathrm{L}$ & $125(86,2)$ \\
Trombositopenia $<100.000 \mu \mathrm{L}$ & \\
\hline
\end{tabular}

Tabel 3. Analisis bivariat faktor prognostik SSD

\begin{tabular}{|c|c|c|c|c|}
\hline \multirow[t]{2}{*}{ Variabel } & \multicolumn{2}{|c|}{ Kelompok } & \multirow[b]{2}{*}{$\mathrm{p}$} & \multirow[b]{2}{*}{ OR (IK95\%) } \\
\hline & $\begin{array}{l}\text { Syok, } \\
\text { n (\%) }\end{array}$ & $\begin{array}{c}\text { Non syok, } \mathrm{n} \\
(\%)\end{array}$ & & \\
\hline \multicolumn{5}{|l|}{ Usia (tahun) } \\
\hline$<5$ & $15(45,5)$ & $18(54,5)$ & 0,191 & $0,592(0,269-1,305)$ \\
\hline$\geq 5$ & $37(33)$ & $75(67)$ & & \\
\hline \multicolumn{5}{|l|}{ Jenis kelamin } \\
\hline Lelaki & $23(31,5)$ & $50(68,5)$ & 0,271 & $0,682(0,345-1,350)$ \\
\hline Perempuan & $29(40,3)$ & $43(59,7)$ & & \\
\hline \multicolumn{5}{|l|}{ Status gizi } \\
\hline Buruk-kurang & $11(26,8)$ & $30(73,2)$ & 0,048 & $2,308(1,004-5,303)$ \\
\hline Lebih-obesitas & $8(25,0)$ & $24(75)$ & 0,048 & $2,538(1,007-6,400)$ \\
\hline Baik & $33(45,8)$ & $39(54,2)$ & Reff & \\
\hline \multicolumn{5}{|l|}{ Nyeri abdomen } \\
\hline Ada & $33(33,7)$ & $65(66,3)$ & 0,427 & $0,748(0,365-1,533)$ \\
\hline Tidak & $19(40,4)$ & $28(59,6)$ & & \\
\hline \multicolumn{5}{|l|}{ Hepatomegali } \\
\hline Ada & $11(26,8)$ & $30(73,2)$ & 0,154 & $0,563(0,254-1,248)$ \\
\hline Tidak & $41(39,4)$ & $63(60,6)$ & & \\
\hline \multicolumn{5}{|c|}{ Perdarahan gastrointestinal } \\
\hline Ada & $10(58,8)$ & $7(41,2)$ & 0,036 & $2,925(1,040-8,226)$ \\
\hline Tidak & $42(32,8)$ & $86(67,2)$ & & \\
\hline \multicolumn{5}{|l|}{ Hemokonsentrasi } \\
\hline Ada & $51(51)$ & $49(49)$ & 0,000 & $45,796(6,072-345,403)$ \\
\hline Tidak ada & $1(2,2)$ & $44(97,8)$ & & \\
\hline \multicolumn{5}{|l|}{ Kebocoran plasma } \\
\hline Efusi pleura & & & & \\
\hline
\end{tabular}




\begin{tabular}{|c|c|c|c|c|}
\hline \multirow[t]{2}{*}{ Variabel } & \multicolumn{2}{|c|}{ Kelompok } & \multirow[b]{2}{*}{$\mathrm{p}$} & \multirow[b]{2}{*}{ OR (IK95\%) } \\
\hline & $\begin{array}{l}\text { Syok, } \\
\text { n (\%) }\end{array}$ & $\begin{array}{l}\text { Non syok, } \mathrm{n} \\
(\%)\end{array}$ & & \\
\hline Ada & $8(40,0)$ & $12(60,0)$ & 0,678 & $1,227(0,467-3,228)$ \\
\hline Tidak & $44(35,2)$ & $81(64,8)$ & & \\
\hline \multicolumn{5}{|l|}{ Asites } \\
\hline Ada & $3(100)$ & $0(0,0)$ & $0,044^{*}$ & $2,898(2,310-3,635)$ \\
\hline Tidak & $49(34,5)$ & $93(65,5)$ & & \\
\hline \multicolumn{5}{|c|}{ Infeksi dengue sekunder } \\
\hline Ya & $20(37,7)$ & $33(62,3)$ & 0,540 & $1,279(0,581-2,817)$ \\
\hline Tidak & $18(32,1)$ & $38(67,9)$ & & \\
\hline \multicolumn{5}{|l|}{ Leukosit, $(\mu \mathrm{L})$} \\
\hline$<5000$ & $14(23,3)$ & $46(76,7)$ & 0,008 & $0,376(0,180-0,785)$ \\
\hline$\geq 5000$ & $38(44,7)$ & $47(55,3)$ & & \\
\hline \multicolumn{5}{|l|}{ Ensefalopati } \\
\hline Ya & $11(78,6)$ & $3(21,4)$ & 0,000 & $8,049(2,130-30,400)$ \\
\hline Tidak & $41(31,3)$ & $90(68,7)$ & & \\
\hline \multicolumn{5}{|c|}{ Peningkatan enzim hati } \\
\hline $\mathrm{Ya}$ & $19(90,5)$ & $2(9,5)$ & 0,000 & $26,197(5,784-118,643)$ \\
\hline Tidak & $32(26,6)$ & $91(73,4)$ & & \\
\hline \multicolumn{5}{|l|}{ Overload } \\
\hline Ya & $18(100)$ & $0(0)$ & 0,000 & $3,735(2,802-4,980)$ \\
\hline Tidak & $34(26,8)$ & $93(73,4)$ & & \\
\hline \multicolumn{5}{|l|}{ AKI } \\
\hline Ya & $1(50$ & $1(50)$ & 1 & $1,804(0,110-29,453)$ \\
\hline Tidak & $51(35,7)$ & $92(64,3)$ & & \\
\hline \multicolumn{5}{|l|}{ Koinfeksi } \\
\hline Diare akut & $1(100)$ & $0(0)$ & 7,357 & - \\
\hline ISK & $1(100)$ & $0(0)$ & & \\
\hline Konjungtivitis & $1(100)$ & $0(0)$ & & \\
\hline Tidak & $48(34)$ & $93(66)$ & & \\
\hline \multicolumn{5}{|c|}{ Imbalans elektrolit } \\
\hline HipoK & $1(100)$ & $0(0)$ & 0,051 & - \\
\hline HipoNa & $5(71,4)$ & $2(28,6)$ & & \\
\hline Tidak & $46(33,6)$ & $91(66,4)$ & & \\
\hline
\end{tabular}

* Uji Fisher Exact

Tabel 4. Analisis multivariat faktor prognostik SSD

\begin{tabular}{lcc}
\hline Variabel & $\mathrm{p}$ & OR (IK95\%) \\
\hline Hemokonsentrasi & 0,001 & $40,035(4,846-330,752)$ \\
Peningkatan enzim hati & 0,001 & $21,827(3,845-123,906)$ \\
\hline
\end{tabular}

cerna, hemokonsentrasi, asites, leukosit $\geq 5000 / \mu \mathrm{L}$, ensefalopati, peningkatan enzim hati dan overload.

Analisis multivariat yang digunakan adalah analisis regresi logistik. Hasil analisis multivariat yang tertera pada Tabel 4 didapatkan variabel dengan $\mathrm{p}<0,05$, yaitu variabel persamaan hemokonsentrasi, EDS, dan peningkatan enzim hati.

Analisis hasil ROC menghasilkan persamaan hemokonsentrasi dan peningkatan enzim hati. Kemampuan diskriminasi dari persamaan tersebut 
dalam membedakan yang diprediksi mengalami sindrom syok dengue adalah baik (area under receiver operating characteristic curve [AUC] 0,818 dengan $\mathrm{p}=$ 0,000 dan IK 95\%: 0,750-0,886).

\section{Pembahasan}

Subyek SSD pada penelitian ini sebagian besar berusia $\geq 5$ tahun yaitu $71,1 \%$. Hal ini dapat disebabkan karena ${ }^{21}$ struktur mikrovaskular yang lebih banyak dan permeabilitas lebih mudah meningkat. ${ }^{11}$

Subyek perempuan dengan SSD lebih banyak, yaitu $61,5 \%$. Respon imun mungkin lebih sensitif terhadap sekresi sitokin pada anak perempuan. ${ }^{6}$ Anak perempuan mungkin memiliki permeabilitas vaskular intrinsik yang tinggi. ${ }^{22}$ Studi $\mathrm{Huy}^{4}$ melaporkan hubungan antara jenis kelamin perempuan dan risiko syok belum dipahami dengan jelas.

Anak DBD dengan malnutrisi dan gizi lebih mempunyai risiko lebih besar terjadi syok atau EDS. ${ }^{4,11,23}$ Aktivitas sistem imun berkembang dengan baik pada gizi baik, gizi lebih dan obesitas, sehingga menyebabkan proliferasi virus meningkat dan manifestasi penyakit yang lebih berat. ${ }^{1,11,24}$ Obesitas dapat memperberat infeksi dengue karena peningkatan produksi jaringan adiposa putih yang menyebabkan peningkatan produksi mediator. Hal ini berakibat kebocoran plasma progresif yang berakhir pada risiko SSD yang lebih tinggi. ${ }^{12}$ Studi Trang ${ }^{25}$ melaporkan tidak ada hubungan yang bermakna secara statistik antara anak DBD dan SSD dengan pasien malnutrisi, gizi lebih, dan obesitas.

Nyeri abdomen dialami banyak $(63,4 \%)$ subyek SSD. Studi Huy menunjukkan bukti yang jelas tentang hubungan nyeri abdomen dan syok dengue. ${ }^{4}$ Nyeri abdomen merupakan petanda aliran darah splanknik berkurang sampai terjadi hipoksia selama pre dan intra syok $^{6}$ serta tanda perdarahan gastrointestinal secara histopatologis. ${ }^{8}$

Penelitian ini mendapatkan hepatomegali pada sedikit $(21,1 \%)$ subyek SSD. Studi Huy melaporkan hepatomegali berhubungan kuat dengan SSD. Hepatomegali mungkin berkaitan dengan galur dan serotipe virus. ${ }^{1}$ Derajat hepatomegali atau nyeri hepar tidak ada korelasi dengan abnormalitas fungsi hati. Hepatomegali merupakan respon normal dari infeksi dengue, tetapi hal ini lebih berhubungan dengan DBD dan SSD dibandingkan dengan DD. ${ }^{26}$
Peningkatan SGOT sebagian besar mungkin diakibatkan kerusakan monosit. Nilai aminotransferase umumnya mencapai maksimum sekitar hari sakit ke-9 dan turun bertahap mencapai normal dalam 2 minggu. Demam berdarah dengue berat (SSD) berhubungan dengan kerusakan hepar akut dan hebat terutama karena infeksi langsung yang masif terhadap hepatosit dan sel Kupfer dengan respon sitokin minimal. ${ }^{19}$

Subyek SSD sedikit $(19,2 \%)$ yang mengalami perdarahan gastrointestinal berupa hematemesis $(15,4 \%)$ dan melena $(3,8 \%)$. Perdarahan akan memperberat kehilangan volume plasma akibat kebocoran sehingga mempercepat terjadinya syok. ${ }^{1}$ Perdarahan dapat disebabkan disfungsi trombosit, vaskulopati dan/atau koagulopati. ${ }^{6}$ Hematemesis dan melena merupakan manifestasi perdarahan berat yang tersering ditemukan. ${ }^{26}$

Hemokonsentrasi $\geq 20 \%$ dialami $98,1 \%$ subyek SSD. Peningkatan hematokrit $\geq 20 \%$ membuktikan peningkatan permeabilitas vaskular, kebocoran plasma, dan berhubungan dengan beratnya penyakit. ${ }^{1,5,12}$ Asites dan efusi pleura pada SSD masing-masing sejumlah 5,8\% dan 15,4\%. Asites, efusi pleura, dan hemokonsentrasi merupakan faktor risiko atau prediktor bermakna syok dengue. ${ }^{4,7,21,26,27}$

Infeksi dengue sekunder dialami $40,4 \%$ subyek SSD. Hal ini mungkin terjadi karena peran antibodydependent enhancement dalam patogenesis SSD. ${ }^{4}$ Sel $T$ teraktivasi selama infeksi sekunder karena interaksi dengan monosit yang terinfeksi sehingga terjadi pelepasan kaskade sitokin seperti interferon gamma, interleukin 2 dan tumor necrosis factor alpha. Proses ini akan menginduksi kebocoran plasma dan berujung pada syok. ${ }^{21}$

Subyek SSD yang mengalami leukopenia berjumlah hanya $25 \%$. Analisis bivariat menunjukkan perbedaan bermakna antara leukopenia dan syok, tetapi sebagai faktor protektif terhadap syok. Leukopenia sampai lekositosis ringan secara nyata selalu terlihat mendekati akhir fase demam. Ketika suhu tubuh turun, banyak pasien mengalami leukopeni akibat supresi sumsum tulang. ${ }^{7}$ Leukopenia mencapai puncaknya sesaat sebelum demam turun dan normal kembali pada 2-3 hari setelah defervescence. ${ }^{28}$

Subyek DBD yang mengalami EDS berjumlah 44 dari 145 (30,3\%) subyek. Jenis EDS pada subyek DBD yang terbanyak, yaitu peningkatan enzim hati $(14,5 \%)$, overload $(12,4 \%)$, dan ensefalopati $(9,6 \%)$. Subyek SSD yang mengalami EDS berjumlah 34 dari 47 
(72,3\%) subyek SSD. Jenis EDS yang terbanyak pada kelompok subyek SSD, yaitu peningkatan enzim hati $(40,4 \%)$, overload $(38,3 \%)$, dan ensefalopati $(23,4 \%)$.

\section{Kesimpulan}

Hemokonsentrasi (peningkatan hematokrit $\geq 20 \%$ ) dan peningkatan enzim hati merupakan faktor-faktor prognosis yang bermakna dalam terjadinya syok dengue berdasarkan analisis multivariat.

\section{Daftar pustaka}

1. Raihan, Hadinegoro SR, Tumbelaka AR. Faktor prognosis terjadinya syok pada demam berdarah dengue. Sari Pediatri 2010;12:47-52.

2. Pawitan JA. Dengue virus infection: predictors for severe dengue. Acta Med Indones 2011;43:129-35.

3. Hadinegoro SR, Moedjito I, Chairulfatah A, penyunting. Pedoman diagnosis dan tata laksana infeksi virus dengue pada anak. Jakarta: Badan Penerbit IDAI; 2014.h.1-6.

4. Huy NT, Van Giang T, Thuy DH, Kikuchi M, Hien TT, Zamora J, dkk. Factors associated with dengue shock syndrome: a systematic review and meta-analysis. Plos Negl Trop Dis 2013;7:1-13.

5. Tantracheewathorn T, Tantracheewathorn S. Risk factors of dengue shock syndrome in children. J Med Assoc Thai 2007;90:272-7.

6. Pongpan S, Wisitwong A, Tawichasri C, Patumanond J. Prognostic indicators for dengue infection severity. Int J Clin Pediatr 2013;2:12-8.

7. Gupta V, Yadav TP, Pandey RM, Singh A, Gupta M, Kanaujiya P, dkk. Risk factors of dengue shock syndrome in children. J Trop Pediatr 2011;57:451-6.

8. Kan EF, Rampengan TH. Factors associated with shock in children with dengue hemorrhagic fever. Pediatr Indones 2004; 44:171-5.

9. Dewi R, Tumbelaka AR, Syarif DR. Clinical features of dengue hemorrhagic fever and risk factors of shock event. Pediatr Indones 2006;46:144-8.

10. Pham TB, Nguyen TH, Vu TQ, Nguyen TL, Malvy D. Predictive factors of dengue shock syndrome in children hospital no. 1 Ho-chi-Minh City, Vietnam. Bull Soc Pathol Exot 2007;100:43-7.

11. Junia J, Garna H, Setiabudi D. Clinical risk factors for dengue shock syndrome in children. Paediatr Indones 2007;47:7-11.

12. Widiyati MMT, Laksanawati IS, Prawirohartono EP. Obesity as a risk factor for dengue shock syndrome in children. Paediatr Indones 2013;53:187-92.

13. Mayetti. Hubungan gambaran klinis dan laboratorium sebagai faktor risiko syok pada demam berdarah dengue. Sari Pediatri 2010;11:367-73.

14. World Health Organization. Comprehensive guideline for prevention and control of dengue and dengue hemorrhagic fever: revised and expanded edition. New Delhi: South East Asian Region Office-World Health Organization; 2011.h.1727.

15. Kadam DB, Salvi S, Chandanwale A. Expanded dengue. J Assoc Physician India 2016;64:59-62.

16. Asuhan nutrisi pediatrik. Panduan praktik klinis departemen ilmu kesehatan anak RSCM. Jakarta: RSCM; 2015.h.306-9.

17. Boamah L, Balistreri WF. Manifestations of liver disease. Dalam: Behrman RE, Kliegman RM, Arvin AM, penyunting. Nelson textbook of pediatric. Edisi ke-18. Philadelphia: WB Saunders; 2007.h.1662.

18. Matondang CS, Wahidiyat I, Sastroasmoro S. Abdomen. Dalam: Matondang CS, Wahidiyat I, Sastroasmoro S, penyunting. Diagnosis fisis pada anak. Edisi ke-2. Jakarta: Sagung Seto; 2000.h.103.

19. Soedarmo SS, Garna H, Hadinegoro S, Satari H. Infeksi virus dengue. Dalam: Soedarmo SS, Garna H, Hadinegoro S, Satari $\mathrm{HI}$, penyunting. Buku ajar infeksi dan pediatri tropis. Edisi ke-2. Jakarta: Badan Penerbit IDAI; 2008. h.155-81.

20. Infeksi virus dengue. Panduan praktik klinis departemen ilmu kesehatan anak RSCM. Jakarta: RSCM; 2015.h.167-82.

21. Pothapregada S, Kamalakannan B, Thulasingham M. Risk factors for shock in children with dengue fever. Indian J Crit Care Med 2015;19:661-4.

22. Phubhakdi CB, Hemungkorn M, Thisyakorn Usa, Thisyakorn C. Risk factors influencing severity in pediatric dengue infection. Asian Biomedicine 2008;2:409-13.

23. Kalayanarooj $S$, Nimmannitya $S$. Is dengue severity related to nutritional status? Southeast Asian J Trop Med Public Health 2005;36:378-84.

24. Halstead SB. Dengue fever/dengue hemorrhagic fever. Dalam: Behrman RE, Kliegman RM, Arvin AM, penyunting. Nelson textbook of pediatric. Edisi ke-18. Philadelphia: WB Saunders; 2007.h.1005-7.

25. Trang NTH, Long NP, Hue TTM, Hung LP, Trung TD. Association between nutritional status and dengue infection: a systematic review and meta-analysis. BMC Infect Dis 2016;16:172-83.

26. Yulianto A, Laksono IS, Juffrie M. Faktor prognosis derajat keparahan infeksi dengue. Sari Pediatri 2016;18:198-203.

27. Ramachandran S, Geral A, Kamall M, Geral R, Roy MP. Changing trends in clinicopathological parameters in dengue 
with evaluation of predictors of poor outcome in children. Int J Contemp Pediatr 2016;3:1411-5.

28. Risniati Y, Tarigan LH, Emiliana Tjitra E. Leukopenia sebagai prediktor terjadinya sindrom syok dengue pada anak dengan demam berdarah dengue di RSPI. Prof. dr. Sulianti Saroso. Media Litbang Kesehatan 2011;21:96-102. 